\title{
John Darwin
}

\section{Tamerlanes skygge}

[Artiklen Tamerlanes skygge er en til Slagmark særligt tilpasset version af sidste kapitel i John Darwins bog After Tamerlane. The Global history of Empire since 1405 fra 2007. Titlen refererer til den sidste af de nomadiske krigsherrer, Tamerlane, der drømte om at realisere et herredømme over hele den eurasiske landmasse. Tamerlane døde i 1405 under et fejlslagent forsøg på at nå Kinas hovedstad. Siden blev den eurasiske scene overtaget af stærke emperier, der ofte har delt Tamerlanes ambition og skæbne.]

Verden af i dag lader sig ikke forklare som et produkt af den globale økonomi og dennes politiske og kulturelle bivirkninger. Bag forskellene i velstand og magt, $\mathrm{i}$ institutionerne og værdierne og i de kulturelle og religiøse bindinger der stadig er så synlige i det 21. århundredes verden, ligger en langt mere kompleks historie om konkurrerende imperie- stats- og kulturdannelse. Men dette er ikke en historie, som er let at efterspore. Den er fortsat kontroversiel. Den fremstilles sommetider som den brutale fortælling om glubsk imperialisme, som Vestens invasion af det hårdtprøvede ikke-Vesten. Det modsatte synspunkt er ligeså skarpt trukket op: verdenshistorien beskrives som den lange march mod modernitet - med Vesten som guide og skabelon. Eftersom ingen af udlægningerne kan vinde andet end partisk støtte er det let at se, hvorfor det kan være tillokkende at falde tilbage på geografisk determinisme. Men selv om det skulle være sandt, at adgangen til større mængder potentielle avlsplanter og husdyr gjorde Eurasien i stand til at erobre 'den ydre verden' og ikke omvendt, ${ }^{1}$ så kan det ikke svare på spørgsmålet om den skiftende magt- og velstandsbalance inden for selve Eurasien i de sidste fem hundrede år.

De to rivaliserende store fortællinger om henholdsvis 'udbytning' og 'modernisering' har, til trods for al den lidenskabelige diskussion som de afføder, begrænset værdi som guide til Eurasiens fortid. Det skyldes ikke, at vi ikke kan finde masser af konkrete beviser for begge fænomener. Men ingen af dem har haft frit spil. Begge er blevet indspundet i politikken og kulturen i de stater og regioner, hvor deres indflydelse har gjort sig gældende. Begge er

[SLAGMARK $51 / 2008 \cdot$ p. 15-30] 
blevet tvunget til kompromisser for at vinde lokale allierede og aktører for sig, uden hvilke de (som regel) var chanceløse. Begge var afhængige af de omskiftelige forhold som begunstigede eller forhindrede imperiale ambitioner, handelsmæssig ekspansion og kulturel manifestation i forskellige egne af verden. Begge var 'projekter' der kunne udhules, overtages eller lammes af sofistikerede former for modstand og tilpasning. Der er ingen velafgrænset kronologi over imperialismens opkomst og fald og ingen velafgrænset geografi for Europas herredømme over resten af Eurasien. Vestens 'imperium' afgik heller ikke ved døden i det koloniale forfængelighedernes bål, som vi kalder afkoloniseringen.

Vi har kort sagt brug for et mere realistisk syn på denne omstridte fortid for at kunne forstå vores egen tid - og må holde op med at se denne tid som et evigtvarende 'nu', men derimod som en historisk periode, der som alle andre er dømt til forandring og forfald. Der må lægges megen vægt på den krogede sti, som den samtidige politiske verden har fulgt på vej mod sin tilblivelse og en sådan udlægning har meget lidt tilfælles med de vejkort over historien som ideologer (af enhver overbevisning) tegner deres lige linier efter. Den foreslår ikke desto mindre, at en række overordnede temaer udgør hjertet af historien - og den tilbyder et glimt af indsigt i Eurasiens og dermed verdens skæbne. Det er disse, vi nu skal se på.

\section{Imperiale historier}

Det er fristende at sige, at verdenshistorien er en imperiehistorie - en historie om imperier. Meget historieskrivning forleder let én til at tro, at imperier er unormale: uvelkomne indblandinger i en ellers ikke-imperial verden. Deres opkomst tilskrives exceptionelle omstændigheder eller den maniske energi hos en unik personlighed. Deres undergang er forudsigelig, fordi de exceptionelle omstændigheder der tillod deres fremvækst, har en begrænset levetid. Dette synspunkt er tiltalende, men derudover har det ikke meget at tilbyde. Et hurtigt blik på verdenshistorien viser tværtimod at imperial magt været udgangspunktet for politikken det meste af tiden. Imperierne var systemer for indflydelse eller herredømme, hvori etniske, kulturelle eller økologiske grænser enten overlappede eller blev ignoreret. Imperiernes allestedsnærvær opstod på baggrund af det faktum, at forudsætningerne for opbygningen af stærke stater var meget ulige fordelt - på en regional skala såvel som på en global. Dette var ikke udelukkende et spørgsmål om dyrkbare landområder eller navigérbare floder, men derimod også om social og kulturel solidaritet og den relative lethed, hvormed både arbejdskraft og varer kunne mobiliseres af staten. Det var denne form for 'modernitet', der tillod opkomsten af et enormt kinesisk 
imperium to hundrede år før vor tidsregning. Det var vanskeligt at gøre modstand mod den kulturelle tiltrækningskraft eller fysiske magtudfoldelse fra den imperiale stats side med mindre modstanden kunne forstærkes af geografisk afstand eller en usædvanlig sammenhængskraft. Selv de stater der undgik underkastelse var nødsaget til at manøvrere rundt blandt imperiale magter for at undgå at blive trampet ned af disse imperiers elefantfødder.

Imperier er almindelige, men de er også forskelligartede. I dag ville de fleste af historiens imperier slå os som beskedne forehavender med små befolkninger og begrænsede rækkevidder. Selv når vi begrænser vores opmærksomhed til de større imperier, så finder vi store variationer. Hvad der af og til kaldes de 'klassiske' imperier var enorme agrarbureaukratier. Deres grundlæggende kendetegn og funktion var kontrol mod jorden, og det den kastede af sig. Et mere eller mindre centraliseret statsapparat - organiseret og rekrutteret for at styrke kejserens magt over for lokale interesser eller jordbesiddende aristokrater indsamlede udbyttet og uddelte imperial justits. Kejserens anseelse var en vital ressource, som der skulle værnes nøje om gennem afsondrethed, ritualer og ceremonier. Efter romerrigets fald i vest var Kina den bedste model for, hvordan et sådant udviklet imperium skulle fungere. Betingelserne var som regel mindre favorable andre steder: Religion, økologi eller den geopolitisk ramme umuliggjorde imperiale styrer som det kinesiske. I det mellemste Eurasien tyede herskere i stedet til brugen af militærslaver - mamelukkerne - rekrutteret fra imperiale randområder. Som fremmede afhængige af Emirens gunst eller som islamiske konvertitter havde de ingen lokale forbindelser, ingen klan eller slægt, der kunne forstyrre deres loyalitet. De udgjorde modvægten til den lokale solidaritet i landsbyerne, hos stammerne og hos den rodfæstede landlige elite. Begge disse former for imperier var således meget forskellige fra de oversøiske imperier, som europxerne begyndte at opbygge mod slutningen af det 15. århundrede.

Disse 'koloniale' imperier opstod naturligvis i mange versioner. De blev som regel ikke etableret gennem statslig aktivitet, men derimod af private eventyrer, der opererede på baggrund af en tilladelse eller et charter udstedt af den hjemlige regering. Nogle var afhængige af at tiltvinge sig arbejdskraften fra dem de erobrede, andre var afhængige af slavearbejdskraft fra Afrika. Nogle prøvede at reproducere (eller ligefrem forbedre) den samfundsform, de havde efterladt i Europa. Dette var de ægte bosættersamfund som både slaver og oprindelige befolkninger stort set blev ekskluderet fra. Disse koloniale former gjorde selvsagt ikke store fremrykninger i Asien. I næsten tohundrede år var Europas invasion af Asien begrænset til baser og depoter - udposter der vendte mod havet, ikke mod kontinentets indre. Bombay, Goa, Pondicherry, Madras, Calcutta, Batavia og Macao. De var en del af merkantile, maritime 
imperier, langs udkanten af Asiens store stater. Deres magt kunne bedst mærkes på de ubeboede vidtstrakte have - når den overhovedet kunne mærkes. Fra slutningen af det 18. århundrede begyndte europæerne at ophobe territoriale besiddelser (hovedsageligt i Sydasien), men da foretrak de at udfylde tomrummet efter tidligere asiatiske herskere snarere end at skabe nye ordner efter 'europæisk' mønster. Det var det mugalske skatteopkrævningssystem i en opstrammet og nedskaleret version, der gav British East India Company de finansielle midler til at opbygge et subkontinentalt herredømme $\mathrm{i}$ århundredet efter slaget ved Plassey (1757).

Det ville være fejlagtigt at skelne for skarpt mellem 'europæiske' og 'asiatiske' metoder. Men i det lange 19.århundrede (1815-1914) blev grundlaget ændret af industriel kraft. Industrielle teknikker tillod europæerne at kolonisere hurtigere og i en langt større skala, end det tidligere var muligt. Det gav dem midlerne til at trænge ind på nye markeder og til at knuse gamle konkurrenter. Det styrkede deres evne til at indsamle information og udnytte den effektivt. Frem for alt forøgede det deres kapacitet til at udstrække deres fysiske magt over langt større distancer og med langt lavere omkostninger. I en tid med dampskibe og senere jernbaner mistede strategisk afsondrethed meget af sin tidligere mening. Hvis en europæisk hær var blevet i stand til at rykke frem mod Nanking (som den britiske var det i den første Opiumskrig i 1839-42) forekom ingen del af Asien længere at være sikker. Et af resultaterne var at man tillod mange flere 'little Indias' - kolonier regeret af europæere - der begyndte at sprede sig over Asien og som også Afrika blev inddelt i efter 1880. Det andet resultat var opkomsten af en tredje slags imperier, imperier baseret på 'usynlig magt'2 ${ }^{2}$ den systematiske akkumulering af udslagsgivende indflydelse over regioner og stater, hvis herskere blev ladt tilbage med en udelukkende nominel suverænitet. Mens europæiske banker, diplomater, handelsfolk, og missionærer nød en privilegeret status, varetog størstedelen af den oversøiske handel, havde hånden på hanen med fremmede investeringer og kunne true med blokade eller bombardement hvis deres interesser blev udfordret, kunne egentlig regeringsførelse forekomme overflødiggjort eller omsonst. Denne form for 'Informel Imperialisme' var - hvis cost-benifit er kriteriet - imperialisme på sit højeste stade.

I teorien var alle slags imperier uundgåeligt udsat for store belastninger og spændinger, for dybe kriser og ultimativt for et fald. Det var en historisk truisme, at intet imperium var permanent - og et kollaps kunne udløses af en lang række årsager. Når et imperium var afhængigt af samarbejdet med eller loyaliteten fra underlagte eliter, så kunne oprør eller modstand på et ubelejligt tidspunkt påføre dets status og autoritet uoprettelig skade. Behovet for at tilfredsstille dets vrangvillige allierede kunne medføre en langsommere, men af 
og til fatal undergravning af kontrollen. Hvis udøvelsen af imperial magt krævede opbakning fra den offentlige mening i det imperiale 'hjemland', eller påførte dets arbejdskraftressourcer eller velstand nye byrder, så kunne et oprør i dets center og ikke i dets periferi være afgørende for, at et imperium gik under. Nye ideologier (eller religioner) kunne ødelægge den moralske og politiske tillid, hvorpå imperier baserede deres legitimitet og ødelægge opfattelsen af, at de var en del af tingenes naturlige orden. Det var en ligeså stor fare at blive klodset: når vægten af forpligtelser blev ubærlig, og smerten ved bortskaffelse for svær at sluge. Imperial overvægt var en belastning for den fysiske styrke og en fristelse for rivaler. Imperier var også udsat for risici forbundet med økonomisk og miljømæssig forandring. De ressourcer og teknologier, som deres magt byggede på kunne tørre ud eller blive forældede. Materiel velstand og teknisk formån kunne smuldre eller rykke til mere gunstige lokaliteter. Mest alvorligt af alt kunne imperier blive drevet ind i gensidigt ødelæggende krige, hvor man i jagten på et afgrænset mål hen ad vejen kunne udløse en verdensændrende uro. Selv uden et sådant dommedagsscenario lurede der en snigende fare inde i de fleste imperiale systemer. Det var nærmest uundgåeligt, at deres beslutningscentre ville falde i hænderne på eliter med gode forbindelser, som ville afsondre sig selv. Gradvist kunne disse eliter gøre den imperiale struktur til et semi-privat domæne beregnet til at fremme elitens egne afgrænsede interesser. De skaffede sig støtte fra andre fraktioner og grupper og etablerede derved en stor koalition, der kunne forsvare den status quo, som de selv havde størst udbytte ved. Denne modvilje i forhold til forandring var en fatal fejl eftersom prisen for et imperium var den konstante tilpasning til hjemlige, koloniale og udenlandske former for pres, og den omgående udnyttelse af kulturelle og økonomiske innovationer. ${ }^{3}$

I sidste del af det 19. århundrede forekom det faktisk som om disse mange kilder til forfald og sammenbrud ville omforme verden. For de fleste vestlige observatører var konklusionen indlysende. De tilbageværende oprindelige imperier i Asien og Afrika - store som små - ville ikke overleve længe. Den periode hvor de med besvær havde eksisteret sammen med de europæiske imperier nærmede sig sin afslutning. Økonomisk stagnation, kulturel senilitet og systematisk korruption havde knækket deres politiske vilje. De besad ikke midlerne til at forsvare deres egne grænser. Deres etniske minoriteter gjorde oprør. Deres økonomiske skibbrud skærpede sociale konflikter. Kulturel stilstand nærede appetitten efter fremmede idéer, men affødte også en xenofobisk eller fanatisk reaktion. Kaos og ruin lå forude - der var tale om 'døende nationer', om fejlslagne imperier. I modsætning hertil havde Europas kolonimagter og deres nordamerikanske fætre efter manges opfattelse opdaget hemmeligheden bag ustoppeligt fremskridt og evigt imperium - den form 
for hybris Kiplings berømte ord advarede imod. ${ }^{4}$ De havde brudt cyklusen bag imperialt forfald. Industrialisering, uorganisk brændstof (kul) og en vidtstrakt ressourcebase, hvorfra man kunne hente varer på tusinder af kilometers afstand, gjorde de miljømæssige begrænsninger irrelevante. Imperiernes handel og kultur ville tiltrække en mængde nye samfund - eller i det mindste disses eliter - hvis loyalitet (eller samarbejde) kunne holde omkostningerne ved imperiet nede. Situationen 'derhjemme' havde også forandret sig til det bedre. Imperium 'on the cheap' samt bevidstheden om, at man var afhængig af fjerntliggende markeder, udgjorde langt mere favorable forudsætninger for at promovere 'imperial' ideologi. 'Nationalstatens' forøgede magt over det hjemlige samfund styrkede idéen om det 'nationale' fællesskab, der om nødvendigt måtte være villigt til at opretholde et imperium. Mest potent af alt forekom det, at indførelsen af 'liberal' politik - mere eller mindre fri konkurrence i det økonomiske og politiske liv - ville være en sikker garanti mod den korrupte privatisering af den politiske magt og mod en rigid forandringsmodstand. Ifølge denne tankegang havde en sådan progressiv mentalitet sin rod i 'race' - et usammenhængende sammensurium af fysiske, sociale og kulturelle karakteristika. Det var derfor europæerne - eller nogle af dem - havde opdaget hemmeligheden bag social evolution. Belønningen antog de at være permanent herredømme over resten af verden.

Det mest sandsynlige udfald forekom at være en ny global orden, hvor magten var delt mellem en håndfuld 'verdensstater'. De tilbageværende stater og imperier i den ikke-vestlige verden ville blive udparcelleret eller blive gjort til nøje overvågede semi-protektorater såfremt de fik lov at eksistere. Der ville blive ydet støtte til 'reformatorer' og 'progressive' med henblik på at knuse modstanden i disse store tilbagestående landes baghaver. Prisen for støtten var accepten af europæiske spilleregler: En åben dør for handel og kultur og nye juridiske regler, der kunne beskytte udenlandske personer og ejendom. Denne æra med formynderskab forventedes at blive lang - måske ville den aldrig ophøre - og med mange tilbagefald. Det gik ikke som spået.

En del af grunden til dette var geopolitisk. Den væsentligste forudsætning for Europas indtrængning i Asien havde været fred i Europa - at storkrig var blevet undgået. De europæiske imperiale rivaliseringer i sidste halvdel af det 19. århundrede lød måske drabelige, men de var blevet håndteret med stor finesse: Skræppen og skryden erstattede faktiske konflikter. Men i 1914 blev denne lange periode med konkurrerende sameksistens brudt for altid og forsøgene på at genoplive den efter krigen kom der meget lidt eller slet intet ud af. Den Europa-centrerede verdensorden blev forladt næsten før den begyndte. Vigtige områder i Eurasien holdt Vesten på afstand på afgørende tidspunkter. Geopolitik var imidlertid kun en del af historien. 


\section{Modstandens monster}

De fleste historier om 'imperium' efter midten af det 18. århundrede deler en generel antagelse: Europæernes koloniale imperier er de eneste imperier, der betyder noget - indtil Japan begynder at overtage den koloniale idé ved indgangen til det 20. århundrede. Dramaet i forbindelse med delingen af Afrika har skabt et forvrænget billede af en uhæmmet imperialisme som ikke lod sig stoppe. Vi får dog et andet indtryk, hvis vi ser nærmere på Asien. På trods af europæernes nippen langs kontinentets maritime kanter og deres opbremsede fremrykning mod slutningen af det 19. århundrede - med Indien som den store undtagelse - så var deres herredømme over Asien i bedste fald partielt. Der kan argumenteres for, at den virkelige historie om Asien i det lange 19. århundrede er historien om Asiens vedholdende modstand og ikke historien om Asiens nederlag. Det store eksempel var Kina som på trods af dynastiske konflikters hærgen, borgerkrig og revolution fastholdt en forunderlig grad af enhed frem til 1914. Idéen om Kina overlevede både afslutningen på det imperiale monarki i 1911 og de fyrre års uroligheder, besættelse og krig, der fulgte i kølvandet. Kinas fastholdelse af sit store asiatiske fastlandsimperium var måske endnu mere overraskende: Manchuriet, Mongoliet, Sinkiang og Tibet. På trods af de håbløse kriser i 1930'erne og 40'erne holdt man sammen på alle dele (med undtagelse af det ydre Mongoliet). Kina har stort set samme grænser som det vidtstrakte Ching Imperium, som europæerne stødte ind i i 1830. Japans vedholdende modstand mod den europæiske udfordring var endnu mere slående. Landets monarki blev genopfundet for at levere den ideologiske lim til en ny politisk orden. Resultatet var en stat, der var stærk nok til at holde til at blive åbnet for Vesten og til snart efter at kaste sig ud i sin egen imperiale løbebane.

Et lignede mønster genfindes i dele af det mellemste Eurasien. De vigtigste muslimske stater i Vestasien gav ikke efter for kolonialisme, selvom de var udsat for Europas kommercielle og fysiske magt. Selvom Det ottomanske Imperium havde mistet sine europæiske provinser inden 1913 og det var blevet tvunget til at afstå sine arabiske besiddelser efter 1918, så undslap dets anatolske kerne, den deling som fredsforhandlerne havde ønsket foretaget. Det blev i stedet til en ny 'tyrkisk' stat. Det iranske imperiums territoriale udstrækning var vokset og siden skrumpet under Safaviderne og Qajarerne men området, der i dag styres af den islamiske republik udgør det meste af det 'historiske' Iran, inklusive de fire store byer Tabriz, Isfahan, Teheran og Mashad. Selv de dele af det mellemste Eurasien (som eksempelvis Ægypten og Indien) hvis politiske form var blevet drastisk ændret af europæisk intervention bevarede eller konstruerede en distinkt identitet, der transcenderede begrænsningerne $i$ en kolonialiseret kultur. 
Hvad muliggjorde dette? En del af svaret var, at europæerne manglede ressourcerne og sommetider motiverne for at fuldstændiggøre globalt imperium. Før 1914 vægrede deres imperiale diplomatier sig ved tanken om at dele Kina, Iran eller Det ottomanske Imperium. Efter 1918 var disses interne splittelser endnu større og opgaven desto vanskeligere. Men dette er kun den ene side af en kompleks ligning. Lige så vigtig var de store asiatiske staters sejlivede traditioner for politisk og kulturel autonomi - traditioner der inddæmmede de fremmede med en usynlig mur. Disse blev forstærket og uddybet af den bølge af 'statsbygning', som gjorde sig gældende i det tidligt-moderne Eurasien, og hvis virkning kunne mærkes over hele den gamle verden og ikke blot $\mathrm{i}$ Europa. Ming-restaurationen, Tokugawa-freden, Safavid-kompromiset og det ottomanske skifte fra en krigerstat til et asiatisk, afrikansk og europæisk imperium var alle lige så slående udviklinger som de nye monarkiske modeller, der blev udformet i Europa. De skabte regeringsformer, der viste sig bemærkelsesværdigt holdbare når udsat for pres. Dynastiske omvæltninger i Kina (fra Ming til Ching) og Irans krisetider i det 18. århundrede kunne muligvis have ødelagt mindre rodfæstede politiske systemer - ikke mindst i Iran med dets sproglige opdelinger og store stammefunderede alliancer.

Disse tidligt-moderne konstruktioner havde blivende betydning. De var med til at opretholde en kontinuerlig regeringspraksis op igennem den periode, hvor presset fra Europa blev stadig mere intenst. De stater som europæerne stod overfor var anciens régimes med fornyelsesbehov, ikke knækkede stater, der var faldet fra hinanden. De der tjente staterne var ofte klare over deres svaghed og behovene for 'reformer'. Men dette indebar etableringen af nye politiske metoder i forlængelse af de eksisterende og ikke indførelsen af en fremmed model, som ingen følte loyalitet overfor. Dette var en afgørende forskel. Kemals republik i Tyrkiet blev bygget på et fundament af ottomanske reformer og ikke grebet ud af den blå luft. Dens 'officielle' version af historien proklamerede ikke Tyrkiets underdanighed over for Europa, men derimod det tyrkiske folks verdenshistoriske betydning. ${ }^{5}$ Dens politiske gudfar var (den i stilhed fornægtede) Sultan Abdul Hamid II (r. 1876-1909) under hvis styre statens kontrol med samfundet blev presset frem med stor energi. ${ }^{6}$ Når Reza Shah Pahlevi (r. 1912-41) skulle hævde sin autoritet over rebelske regioner og stammer kunne han trække på Irans ældgamle monarkiske tradition. Den kejserlige troned [charter oath] gav grønt lys for indførelsen af et langt mere centraliseret styre i Mejii Japan og forhindrede modstandere i at opbygge en ideologisk platform. I Kina indvarslede Ching dynastiets fald et mere fuldstændigt brud med fortiden, men selv her gjorde den nye nationalisme krav på den indre-asiatiske arv efterladt af Ching, og den genoplivede ligeledes det gamle system med overvågning af de enkelte husholdninger med henblik på at 
genvinde social kontrol i de turbulente 1920'ere.

Den vedholdende modstand var kulturel såvel som politisk. Religions, sprogets og litteraturens rolle i skabelsen af nationale identiteter i Europa er en velkendt historie. Der er en række grunde til at nationalstatstanken udviklede sig mere intenst i Europa i tiden for 1914 end i andre dele af Eurasien - ikke mindst som en følge af de revolutioner og krige, der hærgede store dele af kontinentet mellem 1789 og 1815. Over det meste af Eurasien (og inklusiv meget af Østeuropa) fulgte forbindelsen mellem stat og kultur ikke den model, der dukkede op i Vesteuropa. Absolut loyalitet over for en territorial stat og dennes hersker stemte ikke overens med idéen om et islamisk samfund af troende - Ummaen - og koran- og shariafortolkernes autonome autoritet. I det store subkontinentale kinesiske imperium, med dens periferi af mindre, svagere eller afhængige stater manglede der fuldstændigt den styringsmentalitet bag dynastiske konflikter og statsbyggeri, der formede den europæiske nationalisme. I Japan forstærkede to århundredes afsondrethed en stærk mistænksomhed over for udefrakommende, men uden at der var opstået et behov for at identificere japanskhed med en stærk centralstat. Men på trods af at europæernes idé om nationalstaten, som en forening af kultur og politik, kun gav meget lidt mening andre steder, så blev forsøgene på at binde samfundet sammen gennem fælles værdier og praksisser (fra kost og beklædning til historie og kosmologi) taget ligeså alvorligt. Akkurat som i Europa blev lærdomstraditioner i resten af Eurasien fastholdt og videreført af lærere og tekster. Omkring disse samledes de uddannede eliter, der nød social anseelse og som udøvede kulturel autoritet. I Iran og Kina blev denne klasse tæt identificeret med statstanken. Fra Safivid-perioden og frem stod Ulamaen fast på, at den iranske stats vigtigste opgave var at beskytte Shia-islam mod fjendtlige angreb. Shia-islams minoritetsstatus i den islamiske verden gjorde dette endnu mere presserende. I Kina udgjorde den lærde adel både kernen i administrationen og den kulturelle elite i det imperiale system - en rolle de med al sandsynlighed fortsatte med at udfylde i den 'nationalistiske' periode, der fulgte efter. Selv i Indien, hvor det britiske styre gradvist blev påtvunget fra midten af det 18. århundrede, overlevede de før-koloniale traditioner, fordi de allerede var dybt indlejrede i stærke folkesproglige kulturer. Forskellige former for regional patriotisme, idéer om retfærdig regeringsførelse og alternative historieopfattelser levede $\mathrm{i}$ anspændt sameksistens med det koloniale regimes kulturelle apparat. ${ }^{7}$ I slutningen af det 19. århundrede transformeredes de indiske folkesproglige kulturer sig til velorganiserede litterære sprog, og dermed fik de regionale følelser et nyt og kraftfuldt middel til at udtrykke sociale og politiske bekymringer. Uden dette fundament var det nok højst usandsynligt, at den bevægelse hvorigennem Gandhi formåede at gøre indisk nationalisme til et bredt folkeligt anliggende, 
ville have taget til i styrke så hurtigt efter 1914.

Det vigtige i alt dette er, at da Europas kulturelle indflydelse på resten af verden nåede sin største intensitet i slutningen af det 19. århundrede, så stod den over for en stadig mere velorganiseret modstand. Kampen for overlevelse forekom at være tæt for de, der stod vagt om andre eurasiske kulturer. De frygtede et decideret sammenbrud af deres kulturelle traditioner under den vestlige modernitets tidevandsbølge. De var hæmmede af frygten for at miste autoriteten over deres egne lavere klasser, hvis moralske og kulturelle velstand de opfattede sig selv som ansvarlige for. De forstod betydningen af Europas teknologiske forspring og de sociale og kulturelle nyskabelser, der hjalp med at fastholde den, men de var dybt ambivalente i forhold til de moralske og sociale virkninger af disse nyskabelser. Derfor var de meget tiltrukket af versioner af modernitet, der nok var udformet $\mathrm{i}$ Vesten, men som samtidigt forholdt sig stærkt kritisk til Vestens liberale kapitalistiske værdier og imperiale idéer. Gandhis kampagne for at vække masserne fandt sit oprindelige udgangspunkt i Tolstojs idéer om et selvforsynende landligt Utopia. Det tiltrækkende ved Marxisme-leninisme lå i dens løfte om industrielt fremskridt uden den sociale konflikt, der forekom at være kapitalismen iboende. Begge syntes at tilbyde en vej mod modernitet, der kunne kontrolleres. For regimerne, der opstod efter 1918 i Iran, Tyrkiet og i det nationalistiske Kina, for det politiske styre der regerede Indien efter 1947 og (endnu mere udtalt) for det kommunistiske Kina efter 1949, blev den strenge kontrol med udefrakommende kulturelle strømninger ligeså vigtig som opbygningen af barrierer mod udenlandsk industriel magt. Statens øgede rækkevidde gennem uddannelse, medier, propaganda og censur blev brugt til dette formål. Det kan næppe overraske, at dette kom til at fremstå som en kulturel 'belejringsmentalitet'. De kraftige ideologiske storme, der hærgede verden gennem det meste af det 20. århundrede, gjorde et åbent samfund til en farlig leg med skæbnen.

\section{Konvergensbetingelserne}

Dette mønster for en vedholdende politisk og kulturel modstand giver ikke meget mening, hvis det står alene. Mønstret kan ikke forklares uden en redegørelse for de materielle forudsætninger, som herskere og eliter i forskellige dele af Eurasien forfulgte deres målsætninger på baggrund af. Udsigterne til at bevare kulturel autonomi og politisk frihed afhang til dels af økonomisk succes. Og udsigterne var også uvægerligt influeret af den eksterne handels magnetiske tiltrækningskraft og af det som udefrakommende ville sælge. I enhver periode af verdenshistorien (og ikke mindst i dag) er gevinsterne ved samhandel og ved at åbne døren for udenlandske produkter blevet modsva- 
ret af kulturelle og politiske risici. Lige under overfladen har der næsten altid luret en frygt for at blive domineret af eller indlemmet $i$ handelsmæssige 'stormagter' og for på usynlig vis at blive kolonialiseret af udenlandsk ejede foretagender og disses lokale kollaboratører. Det samme har frygten for, at nye former for produktion eller nye former for forbrug ville skabe en ødelæggende social og kulturel forandring. Derfor har betingelserne for økonomisk samkvem - betingelserne for adgangen til den globale økonomi - altid været af afgørende betydning.

Der kan fremsættes et stærkt argument for, at en form for global økonomi opstod i det 16. århundrede. ${ }^{8}$ Der opstod en helt ny form for udvekslinger, så snart Amerika var blevet forbundet med Eurasien og Afrika. Sølv fra Amerika gjorde det muligt for Europa at købe langt større mængder tekstiler, porcelæn og te fra de Syd- og Østasiatiske producenter. Amerikansk sukker betalte for importen af (hvad der med tiden blev til) millionvis af afrikanske slaver og forøgede indirekte afrikanernes forbrug af de handelsvarer, som slaverne blev købt for. Amerikanske fødevarer som kassava, majs, bønner og kartofler forandrede (i visse områder) Europas, Asiens og Afrikas landbrugspotentiale. Et lukrativt netværk af søveje over lange distancer medvirkede til at gøre Europa til en stor maritim handelsplads, der regerede havene. Men denne tidlig-moderne verdensøkonomi (1500-1750) gav ikke Europa nogen afgørende fordel i forhold til resten af Eurasien. Den forøgede Europas afhængighed af Asiens produkter, men den tilbød få måder hvorpå Europa kunne forøge sin andel af det asiatiske forbrug. ${ }^{9}$

Dette mønster ændrede sig dramatisk efter 1750, men ikke på én gang. Briternes opportunistiske overtagelse af den bengalske økonomi gav dem en chance for at ændre betingelserne for deres handel med Kina. Indien kom til at levere den opium og blev gjort til den militærbase, der gjorde det muligt for briterne at tvinge sig adgang til den østasiatiske handel. Opkomsten af den mekaniserede produktionsform i Europa var dog den afgørende forandring. I løbet af få årtier mistede Asien sine tekstileksportmarkeder til den europæiske konkurrence og de europæiske beklædningsstoffer fandt ligefrem vej ind i Indiens og Kinas hjemlige tekstiløkonomier. Verdenshandlen begyndte nu at vokse hastigt. Den blev omkring 25-doblet i løbet af det lange 19. århundrede, men de betingelser som Asien nu handlede med Europa på efterlod langt mindre manøvrerum. Europæerne kontrollerede netværkerne bag langdistancehandlen og leverede dens mest værdifulde varer. For at blive en del af denne handel og for at kunne betale for de europæiske produkter blev de asiatiske økonomier tvunget til at falde tilbage på eksport af råvarer og fødevarer og for at gøre situationen endnu værre, set fra et asiatisk synspunkt, så var man også i konkurrence med producenter fra såvel den atlantiske økonomi som internt. 
Amerikansk bomuld og hvede lå $\mathrm{i}$ konkurrence med den indiske; indisk te erstattede den kinesiske på det britiske marked. I kraft af deres kontrol med den asiatiske søvejshandel, deres nyvundne adgang til asiatiske forbrugere (gennem erobringer i Indien og gennem påtvungne handelsaftaler i Kina) og deres store industrielle forspring, så var det som om, at Europa havde trukket de asiatiske økonomier ind på et globaliseret marked på det tidspunkt, hvor kløften imellem deres relative styrke var størst. Tallene er sigende. Mens Indiens og Kinas bruttoindenrigsprodukt pr. indbygger i 1820 lå på cirka det halve af niveauet i Vesteuropa lå det i 1913 snarere på en syvendedel. ${ }^{10}$

Dette dystre billede fortæller ikke hele historien. Asien blev en del af en ny global økonomi, hvori vareudvekslingen var enormt meget større end før 1750. Men europæernes kontrol over de asiatiske økonomier var langt fra fuldstændig - og det af en række grunde. De havde for lidt kapital til fuldstændigt at 'kolonialisere' de asiatiske producenter. De var forbløffede over vanskelighederne ved at trænge dybere ind i Asiens største økonomi. Kinas sprog, valutasystemer og indenlandske merkantile netværk holdt dem i skak. Og tiden var heller ikke på deres side. Vi skal langt på den anden side af århundredets midte førend jernbanebyggerier, Suez kanalen, dampskibet og telegrafen bragte selv det maritime Asien så tæt på Europa, som de transatlantiske økonomier længe havde været. Timingen var særligt betydningsfuld i forhold til Japan hvor industrialiseringen var godt undervejs i 1880'erne. I stedet for at blive reduceret til en subaltern region udløste Japans eksport til Vesten og den indtægt som denne skabte en hastigt voksende handel internt $\mathrm{i}$ Asien mellem asiatiske økonomier. Snart var det japanske industrialister (ofte i partnerskab med kinesiske handelsfolk) og indiske ejere af tekstilmøller, der opfyldte regionens behov for forbrugsvarer. Frem mod 1914 voksede Asiens handel med Asien hurtigere end dens handel med Vesten. ${ }^{11}$

De hundrede år frem mod 1914 kan således beskrives som en periode med 'semi-globalisering'. Man var her vidne til opkomsten af ét sammenhængende verdensmarked for primære og industrielle produkter såvel som for kapital og finansielle ydelser. I en række stater (men dog ikke i flertallet) var andelen af udenrigshandel vokset betydeligt $i$ forhold til statens samlede produktion. Andelen var dog stadig langt lavere end det niveau, der blev nået ved slutningen af det 20. århundrede. ${ }^{2}$ Og bortset fra Østasien, så var produktionsindustrien blevet kraftigt koncentreret omkring det atlantiske Europa og det gamle nordøst i De Forenede Stater. Ingen anden del af verden kunne konkurrere på industrivarer på disse markeder. Semi-globaliseringen var tæt på at gå helt i stå ved krigens udbrud i Europa. Den økonomiske integration fra tiden op til 1914 blev sat i bakgear i den periode af sammenbrud, der fulgte efter. Efter en kortvarig bedring sidst i 1920 'erne skrumpede den globale økonomi. Dens 
vigtigste anløbsplads, Storbritannien, gik bort fra den politik, der havde fået dens udvekslinger til at glide: En guldfunderet verdensvaluta og en forpligtelse på frihandel. Verdens største økonomi, nemlig USA's, trak sig længere tilbage i sin protektionistiske hule. Størstedelen af resten af verden blev opdelt i blokke: Hver under sin hegemon og hver med det formål at indskrænke handlen med de øvrige dele af verden. Sovjetunionen trak sig nærmest tilbage $\mathrm{i}$ isolation. Mindre stater kæmpede for at mindske deres eksterne afhængighed. Producenter af primærprodukter oplevede deres indkomst kollapse. Den asiatiske økonomi - hvor Kina havde industrialiseret hastigt - blev nu delt i to. Først af Japans 'yen blok' og siden (i 1937) af dets invasion af Kina. Da verden mobiliserede til en ny altomfattende krig kunne den store handelsekspansion fra det forrige århundrede ikke længere ses som en guide til fremtiden. Den lukkede økonomi - selvforsyning og intern udvikling frem for øget samhandel - var blevet prisen for overlevelse i en opdelt verden.

Denne udsigt forandrede sig ikke fuldstændigt efter 2. verdenskrig. Da efterkrigstidens genopretning endelig indfandt sig, så afspejlede den de splittelser, der ikke var blevet løst ved freden. Visionen om global frihandel, der havde inspireret til oprettelsen af IMF (Den internationale valutafond), Verdensbanken og GATT (the General Agreement on Tariffs and Trade) stod over for en virkelighed bestående af en global kold krig. Sovjetunionens autarkiske imperium ekspanderede kraftigt i Øst- og Centraleuropa. Den kommunistiske triumf i Kina forstærkede yderligere den opdeling af den østasiatiske økonomi, der var blevet indledt før krigen. Som det stalinistiske Rusland trak Kina sig tilbage i planlagt isolation. Sydkorea, Taiwan, Hong Kong og Singapore fulgte Japans vej og blev dets handelspartnere. Det europæiske fællesmarked - katalysatoren i den vesteuropæiske genopretning, etablerede en protektionistisk blok. Den økonomiske organisation afspejlede dets primære formål: At sikre en permanent afslutning på de fransk-tyske stridigheder - ikke fremmelsen af en åben global økonomi. Da de europæiske oversøiske imperier splittedes op i en mængde nye stater foretrak de fleste en lukket statsstyret økonomi i forsøget på at opbygge en industriel base og tilbød deres diplomatiske støtte til gengæld for hjælp og investeringer fra de rivaliserende supermagter. Måske var det dog omfanget af den amerikanske magt, der var det mest betydningsfulde træk ved denne genoprettelsesperiode. Det var Anden Verdenskrig der havde gjort USA til ikke blot den største, men også den stærkeste økonomi i verden. Det var den globale kolde krig, der gjorde landet til verdens stærkeste militærmagt. Det var med disse aktiver, at USA trådte ind i den 'globaliserede' verden ved århundredets slutning.

Der er nu sagt nok til at en indlysende pointe kan slås fast. Den økonomiske orden, som vi har vænnet os til i det sidste halvandet årti, udgør et ekstraor- 
dinært øjeblik i den globale økonomis turbulente historie. Den blev skabt af et jordskælv mere dramatisk end noget andet i den moderne verdenshistorie. Det krævede en kombination af geopolitisk forandring - Sovjetunionens pludselige kollaps og Kinas beslutning om at slå ind på markedsøkonomi - og en teknologisk revolution indenfor kommunikation og transport. Vendingen mod markedet i Folkerepublikken og i den tidligere Sovjetblok skabte en massiv forøgelse af produktionskapaciteten og et enormt nyt marked. Dette faldt sammen med etableringen af en langt billigere lufttrafik, med 'containerrevolutionen' i skibstransporten, og frem for alt med den kommercielle anvendelse af internetteknologi. I slipstrømmen på 1980'ernes finansielle 'liberalisering', der skabte langt større frihed for finansielle ydelser og kapitaloverførsler mellem vestlige lande, blev betingelserne for en periode med en exceptionel stigning i samhandlen og en intens integration af de økonomiske aktiviteter på global skala opfyldt - og det i en grad som langt oversteg de begrænsede udsigter i verdenen før 1914. 'Den store divergens' i velstand og økonomisk formån mellem det euro-atlantiske Vesten og det meste af det resterende Eurasien er blevet afløst af 'Den store konvergens' der, såfremt den fortsætter, $i$ løbet af de næste halvtreds år vil genskabe balancen $i$ retning af det omtrentlige ekvilibrium, der eksisterede for fem hundrede år siden.

Den verden, som 'globaliseringen' er i færd med at genskabe, er imidlertid i vid udstrækning blev til på meget anderledes betingelser. I de sidste fem hundrede år har de økonomiske forbindelser mellem forskellige dele af verden gjort meget lidt for at forhindre (og en hel del for at tilskynde til) opbygningen af imperier, stater og kulturer med distinkte værdier, holdninger, institutioner og ideologier. Historisk set har gensidig økonomisk afhængighed - den væsentligste begrænsning af kulturel diversitet - været for kortlivet, for hurtigt forladt og for begrænset i sin indvirkning til at kunne vende denne udvikling. Det antages generelt at denne lange æra står foran sin afslutning: At folkelige kulturer og nationalstaten ikke kan modstå de frembrusende virkninger af en verden med fri bevægelighed af informationer, mennesker og varer. Indtil nu har den frie bevægelighed kun fået lov at køre kortvarigt. Vi må vente og se.

\section{Tamerlane's skygge}

Dette er muligvis pointen. Det kan meget vel være, at vi nu står på tærsklen til en større omvæltning - i geopolitik, økonomi og kultur - der er mindst ligeså vidtrækkende som den eurasiske revolution i slutningen af det 18. århundrede. Hvis det forholder sig sådan, kan der næppe være tvivl om, at dens indvirkninger $i$ forskellige dele af verden vil variere enormt. Eurasiens historie indikerer, at selvom nye former for krigs- og regeringsførelse, nye produktionsteknikker, 
nye kulturelle praksisser og nye religiøse strømninger har spredt sig fra den ene ende af den gamle verden til den anden (og i enhver retning), så har disse ikke tilvejebragt en fælles opfattelse af modernitet eller af, hvad det ville sige at være 'moderne'. Fortidens mønstre af handel og erobring, diasporaer og migration, der har skubbet og trukket regioner sammen og formet deres kulturer og politik har været exceptionelt komplekse. Deres virkninger har ikke været at homogenisere verden, men at fastholde dens diversitet. I modsætning hertil har den globale økonomis magnetiske kraft indtil nu været for flakkende og haft for spredt effekt til at fremtvinge den kooperative adfærd og kulturelle sammensmeltning, som frihandelsteoretikere ofte har set frem mod. Hvad vi i dag kalder globalisering kan måske på ærligste vis forstås som udspringende af en række nylige aftaler - nogle uudtale andre formelle - mellem de fire store økonomiske 'imperier' i nutidens verden: USA, Europa, Japan og Kina. For dem, og for alle andre stater og samfund, bliver udfordringen at forene deres indre sammenhængskraft med den frie konkurrences forandrende virkninger. Presset vil blive stort og udfaldet er usikkert. Men hvis der er én kontinuitet, som vi er i stand til at udlede fra et langt tilbageblik på fortiden, så er det Eurasiens modstand mod ét ensrettet system, mod én enkelt stor hersker eller ét sæt af regler. I den forstand lever vi stadig i Tamerlanes skygge - eller måske mere præcist i skyggen af hans forlis.

Artiklen er oversat af Casper Andersen fra John Darwin: "After Tamerlane. The global history of empire since 1405", Penguin Publishers Group. Artiklen bringes i Slagmark med tilladelse fra Penguin Publishers Group.

\footnotetext{
Noter

${ }^{1}$ Dette er argumentet i J. Diamond, Guns, Germs and Steel (London 1997).

2 Idéen om 'informelt imperium' blev udviklet af J. Gallagher og R. Robinson i den berømte artikel 'The imperialism of Free Trade', Economic History Review, New Series, 6, I (1953), pp. 1-15.

${ }^{3}$ Betydningen af hævdvundne interesser for skabelsen af stagnation er blevet påpeget af M. Olson i The Rise and Fall of Nations: Economic Growth, Stagflation and Social Rigidities (New Haven 1982).

${ }^{4}$ R. Kipling, 'Recessional' (1897).

${ }^{5}$ Se B. Ersanli, 'The Empire in the Histriography of the Kemalist Era', i F. Adanir og S. Faroqhi (eds.), The Ottomans and the Balkans : A Discussion of Historiography (Leiden 2002), pp. 115-54.

${ }^{6}$ Se S. Deringil, The Well-Protected Domains: Ideology and the Legitimation of Power in the Ottoman
} 
Empire, 1876- 1909 (London, 1999).

${ }^{7}$ C.A. Bayly, Origins of Nationality in South Asia: Patriotism and Ethical Government in the Making of Modern India (New Delhi, 1998), Kap. 1-4.

${ }^{8}$ De væsentligste fortalere for dette synspunkt er D.O. Flynn og A. Gialdez. Se deres 'Path Dependence, Time Lags and the Birth of Globalisation', European Economic History Review, 8 (2004), pp. 81-108.

${ }^{9}$ For argumentet om at globaliseringen opstod i det 19. århundrede, K.H.O Rourke og J.G. Williamson, 'Once more: When did Globalization Begin?', European Economic History Review, 8 (2004), pp. 109-17

10 Se 'Growth and Development Trends 1960-2005', i United Nations World Economic and Social Survey 2006, p. 5, http://www.un.org/esa/policy/wess/wess2006files/chapI.pdf.

11 Se K Sugihara (ed.), Japan, China, and the Growth of the Asian International Economy, 18501949 (Oxford, 2005), 'Introduction', p. 5.

12 Se R. Findlay og K.H. O’Rourke, Commodity Market Integration 1500-2000, National Bureau of Economic Research Working Paper (Boston, 2001), tabel 3. 